\title{
Dental manifestations of congenital rubella syndrome
}

\author{
Ruchi Ahuja, ${ }_{1}^{1}$ Anand L Shigli, ${ }^{2}$ Gagan Thakur, ${ }^{3}$ Upendra Jain ${ }^{4}$
}

${ }^{1}$ Department of Pedodontics and Preventive Dentistry, Peoples' College of Dental Sciences and Research Centre, Bhopal, Madhya Pradesh, India ${ }^{2}$ Department of Pedodontics and Preventive Dentistry, Bharati Vidyapeeth Dental College, Sangli, Maharashtra, India

${ }^{3}$ Department of Oral and Maxillofacial Surgery, Peoples' College of Dental Sciences and Research Centre, Bhopal, Madhya Pradesh, India ${ }^{4}$ Department of Orthodontics, Peoples' College of Dental Sciences, Bhopal, Madhya Pradesh, India

\section{Correspondence to} Dr Upendra Jain, bracesuppujain@gmail.com

Accepted 3 February 2015

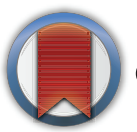 \\ CrossMark}

To cite: Ahuja R, Shigli AL, Thakur $\mathrm{G}$, et al. BMJ Case Rep Published online: [please include Day Month Year] doi:10.1136/bcr-2015209382

\section{DESCRIPTION}

Congenital rubella syndrome (CRS) has a low incidence and has been expected to reduce to $1 / 100000$ live-births. The infection can be acquired by contact with the togavirus family of microorganisms during pregnancy. Fetal development is completely paralysed once the microorganism is transmitted to the fetus. ${ }^{1}$

Patients with CRS are usually categorised as special patients with exaggerated dental problems usually due to lacking manual dexterity and failure on the part of caretakers to provide timely oral disease prevention as they consider it secondary owing to the grave systemic problems the patient suffers from. ${ }^{2}$ Treatment cannot be performed in a routine setup but requires physical restraints or sedation to cope with the patient's physical and intellectual limitations. ${ }^{3}$

In the present case, a 4-year-old girl had CRS with severe hearing disorders, congenital cardiopathy (ventricular septal defect, VSD) for which she had undergone surgical intervention 1-year prior. She had a minimal attention span and poor ability to respond to instructions given. Her mother revealed that as the child was unable to chew, her diet usually comprised of soft foods. Intraoral examination revealed not all teeth were cariously involved, however, the lower anterior teeth were diagnosed congenitally missing owing to a knife edged alveolar ridge (figure 1). Also, the maxillary arch was unusually narrow and the palate was deep (figure 2). Symptomatic relief of pain was provided by excavation and temporisation in decayed teeth.

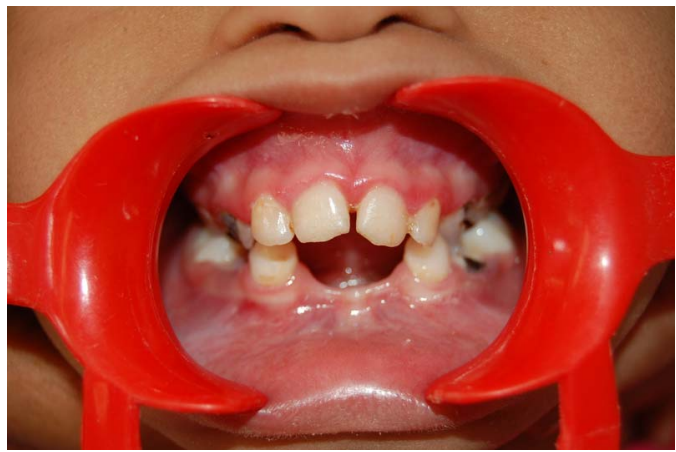

Figure 1 Congenitally missing lower incisors.

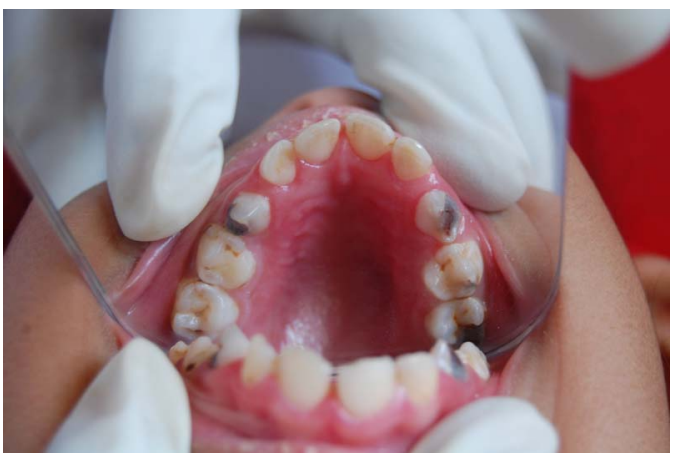

Figure 2 Constricted maxillary arch and high palate.

Comprehensive treatment could not be planned under general anaesthesia due to the unwillingness of the parents for the procedure.

\section{Learning points}

- Congenital rubella syndrome (CRS) can be acquired by contact with the togavirus family of microorganisms during pregnancy.

- Patients with CRS are usually categorised as special patients with exaggerated dental problems usually due to lacking manual dexterity.

- Treatment cannot be performed in a routine setup but requires physical restraints or sedation to cope with the patient's physical and intellectual limitations.

\section{Competing interests None.}

Patient consent Obtained.

Provenance and peer review Not commissioned; externally pee reviewed.

\section{REFERENCES}

1 Chakravarti A, Jain M. Rubella prevalence and its transmission in children. J Clin Virol 2006;35:285-91.

2 Sanger R, Casamassimo P. The physically and mentally disabled patient. Dent Clin North Am 1983;27:363-84.

3 Castro GF, Castro RA, Souza IP. Paciente pediátrico com doença sistêmica: consideraçôes sobre a importância do atendimento primário ao paciente especial. Rev fo/uerj 2001;7:42-6. 
Copyright 2015 BMJ Publishing Group. All rights reserved. For permission to reuse any of this content visit http://group.bmj.com/group/rights-licensing/permissions.

BMJ Case Report Fellows may re-use this article for personal use and teaching without any further permission.

Become a Fellow of BMJ Case Reports today and you can:

- Submit as many cases as you like

- Enjoy fast sympathetic peer review and rapid publication of accepted articles

- Access all the published articles

- Re-use any of the published material for personal use and teaching without further permission

For information on Institutional Fellowships contact consortiasales@bmjgroup.com

Visit casereports.bmj.com for more articles like this and to become a Fellow 